\title{
Morphological Changes of the Cellularity in the Prostatic Gland from Patients with Confirmed Cancer: Gleason Level and Presence of Eosinophils and Mast Cells: Cellular Bioindicators
}

\author{
Cambios Morfológicos de la Celularidad en la Glándula Prostática de Pacientes con Cáncer \\ Confirmado: Nivel de Gleason y Presencia de Eosinófilos y Mastocitos: Bioindicadores Celulares
}

Rodríguez, Héctor ${ }^{1}$; Cortés-Chau, Felipe ${ }^{1}$; Cortés-Pino, Felipe ${ }^{1}$; Aguirre, Pablo ${ }^{1}$ Bravo, Gonzalo ${ }^{1}$; Gallegos, Iván ${ }^{1}$; Arriaza, Camilo'; Cuéllar, Caroll'; Aguayo, Francisco1 \& Espinoza-Navarro, Omar ${ }^{2}$

RODRÍGUEZ, H.; CORTÉS-CHAU, F.; CORTÉS-PINO, F.; AGUIRRE, P.; BRAVO, G.; GALLEGOS, I.; ARRIAZA, C.; CUÉLLAR, C.; AGUAYO, F. \& ESPINOZA-NAVARRO, O. Morphological changes of the cellularity in the prostatic gland from patients with confirmed cancer: Gleason level and presence of eosinophils and mast cells: Cellular bioindicators. Int. J. Morphol., 38(4):882-887, 2020.

SUMMARY: The different pathologies of the prostate, involve the presence of a new microenvironment where inflammatory cells are actively recruited. This research explores the presence of mast cells and eosinophils associated with age and the evaluation of prostate cancer progress (Gleason Index). Forty two biopsies of anonymized patients, with confirmed prostate cancer, were used for histological analysis for eosinophils and mast cells and subsequent determination of Gleason index according to age. The results of the histological analyzes show the presence of eosinophils and mast cells in prostate biopsies with confirmed cancer. In the multiple correlation studies, a high correlation was observed between the presence of lymphocytes and the age of the patient diagnosed with prostate cancer, same correlation was observed between the patient's age and higher Gleason Index (Pearson and Spearman p< 0.05). It is concluded that in prostate biopsies from Chilean patients with confirmed cancer, eosinophilia and tissue mastocytosis were observed. Correlation analyzes show a direct correlation between older patients, higher Gleason index and presence of mast cell. Regarding eosinophilia, only a correlation between age and Gleason index was observed Further studies are suggested to determine that the presence of eosinophils and mast cells can be used as early bioindicators of prostate cancer.

KEY WORDS: Prostate bioindicators; Early diagnostic; Cancer; Cellular microenvironment.

\section{INTRODUCTION}

The prostate is an alveolar tubule exocrine gland composed of a branched excretory duct and abundant broad lumen secreting adenomeres. In parallel, the stroma is mainly composed of smooth muscle fibers, distributed in a direction parallel to the basal lamina of the epithelia and strongly acidophilus cytoplasm. This composition and organization are basic for the maintenance of the structural integrity of the gland. In a normal prostate, it is not possible to find eosinophils and mast cells (Wong \& Tam, 2002).

The various pathologies of the prostate, chronic inflammation, angiogenesis, and cancer, involve the presence of a new microenvironment in the connective tissue where inflammatory cells are actively recruited into the tumor microenvironment (Carmeliet, 2003; Kimura et al., 2007;
Chao et al., 2017). However, the arrival of a noxa, adverse agent, to the stroma implies relative and drastic changes in local biochemistry and cellularity that could be a chain and endless reactions. Cancer cells could change a normal microenvironment to one that supports tumor growth, metastasis and induction of angiogenesis and inflammation (Chao et al.).

Prostate cancer (PCa) is the most frequently diagnosed cancer and the second leading cause of cancer death among men in Western countries. Current screening techniques are based on the measurement of serum prostatespecific antigen (PSA) levels and digital rectal examination. A definitive diagnosis of $\mathrm{PCa}$ is based on prostate biopsies (Lima et al., 2016).

\footnotetext{
${ }^{1}$ Facultad de Medicina, Universidad de Chile, Chile.

${ }^{2}$ Facultad de Ciencias, Departamento de Biología, Universidad de Tarapacá, Arica, Chile.

Funding: This work was funded by project UTA Mayor No. 4716-17, Universidad de Tarapacá, Arica-Chile.
} 
RODRÍGUEZ, H.; CORTÉS-CHAU, F.; CORTÉS-PINO, F.; AGUIRRE, P.; BRAVO, G.; GALLEGOS, I.; ARRIAZA, C.; CUÉLLAR, C.; AGUAYO, F. \& ESPINOZA-NAVARRO, O. Morphological changes of the cellularity in the prostatic gland from patients with confirmed cancer: Gleason level and presence of eosinophils and mast cells: Cellular bioindicators. Int. J. Morphol., 38(4):882-887, 2020.

Incidence increases with patient age and represents the most important risk factor. PCa is mostly characterized by indolence; however, in a small percentage of cases $(3$ $\%)$, the disease progresses to a metastatic state. To date, the most important issue concerning $\mathrm{PCa}$ research is the difficulty in distinguishing indolent from aggressive disease (Pin et al., 2013).

For the development of prostate cancer, genetic, environmental, and other factors have been mentioned. However, age seems to be one of the most determining factors, varying the state of progress and degree of malignancy of the disease according to the patient's age. The degree of cancer progression is defined according to the histological morphometric analysis (biopsy), where the degree of tumor differentiation of the glandular and connective tissues is estimated (Pin et al.).

Aging is a complex process characterized by an immunosenescence, which has a significant adverse effect on the remodeling or differentiation of immune system cells. It is possible to describe inflammation as one of the main causes of age-related deterioration and differentiation of immune system cells, which participate with an important role in the development of age-related diseases (McEllistrim et al., 2017).

Mast cells are recognized cells in cancerous tissues and very poorly in normal tissues, have a phenotypic heterogeneity associated with their enzymatic characteristics, and their finding in confirmed cancer biopsies allows their presence to be associated with tumorigenesis and prognosis. The activation of ion channels; as well as the release of inflammatory mediators such as histamine, proteases (serine), leukotrienes, heparin, serotonin and purinergic signaling, would be a set of cellular and tissue processes that would alter the microenvironment and endogenous homeostasis constituting a conducive network to trigger a process of oncogenicity (Globa et al., 2014; Gao \& Jacobson, 2017).

The action of eosinophils develops given the versatility of their functions in tissues and can act as macrophages, antigen-presenting, and lymphocyte activating cells (Akuthota et al., 2008). Evidently, eosinophils participate through modulation of the innate and adaptive immune response, interacting with mast cells and $\mathrm{T}$ cells, that together regulate the immune response and inflammatory status (Hogan et al., 2008).

Although very little is known about the direct or indirect regulatory relationships of the development of carcinogenesis in the human prostate, the involvement of eosinophils in various septic and non-septic inflammatory processes is clear, although not their progress towards cancer.
Currently, there is evidence that significantly relates to the inflammatory process to the development of cancer. Inflammation can play potentially dichotomous roles (pro and anti-tumorigenic) depending on the nature and cellular composition of the immune response (Sfanos et al., 2014).

The present investigation explores the tissue characterization of the presence of mast cells and eosinophils associated with age and the evaluation of prostate cancer progress (Gleason index).

\section{MATERIAL AND METHOD}

Forty-two biopsies of patients with confirmed prostate cancer, fixed in formalin and embedded in paraffin, were used for histological analysis and to determine the Gleason index. Samples were collected at "biopsy bank" from San Borja Arriarán Hospital and "biopsy bank" from José Joaquin Aguirre Hospital of Santiago, Chile. In access to biopsies, the corresponding protocols were followed (Rodríguez et al., 2015; Ministerio de Salud, 2015). The samples were obtained and processed prior to the anonymization of the individuals (Data Bank Unit, according to CEIMS protocols, 2015). From the pathological certificate, prior to its anonymization, information on the age and diagnosis of prostate cancer was obtained with its minor, major, and total Gleason evaluations (Gleason index) for each patient. The surgical biopsy samples were fixed in $10 \%$ formalin buffered in phosphate saline solution $\mathrm{pH} 7.2$, having been maintained for a minimum period of 48 hours. Later in the Morphology laboratory, the samples were processed by routine histological techniques. From each of the biopsies, $5 \mu \mathrm{m}$ thick sections were obtained in strips of 10 sections, which were placed on high adhesion slides. Subsequently, the sheets were subjected to histological techniques of aqueous staining with $1 \%$ Toluidine Blue, for the evaluation of mast cells and metachromasia (Sridharan \& Shankar, 2012). For the staining of tissue eosinophils, the technique was used based on Giemsa and methylene blue dyes, and subsequently observed and quantified under an optical microscope. All observations were made with a 40x objective (field diameter of $0.17 \mathrm{~mm}^{2}$ ). Quantifications of 100 fields were made per biopsy and per patient (individual average), of which an average was obtained that was tabulated together with the other variables considered: Age and Gleason index.

Statistic Analysis. Both cellular variables, mast cells and eosinophils were analyzed by the Kolmogorov-Smirnov test procedures to analyze whether they corresponded to normal 
or non-normal distribution variables. Then, a correlation type relationship analysis was carried out using the Pearson and Spearman coefficients, always considering values of $\mathrm{p}<0.05$ and $\mathrm{p}<0.01$, respectively. A multiple correlation study was developed for all the variables considered.

\section{RESULTS}

The prostate is classified as a tubular-acinar gland with broad lumen and stroma with abundant smooth muscle fibers. The photomicrographs and table show the histology of normal prostate and prostate with confirmed cancer and the correlation between age, Gleason index and the presence of eosinophils and mast cells.

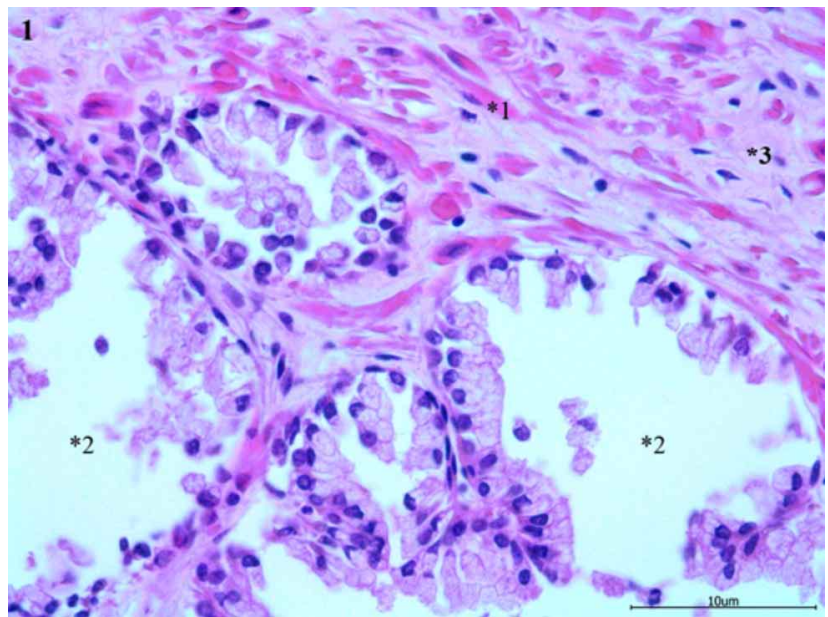

Fig. 1. Photomicrograph of the histology of normal prostate. Hematoxylin and Eosin staining. Increase to $40 \mathrm{X},\left(0-17 \mathrm{~mm}^{2}\right.$ field diameter) reference bar $10 \mu \mathrm{m}$.
Figure 1 shows the normal prostate histology. In the parenchyma of the gland, broad glandular acini with a pseudostratified secretory epithelium of varying height were observed $(* 1)$. While in the stroma, the connective tissues $(* 3)$ proper and smooth muscle $(* 2)$ stand out, both compartments of normal histological appearance.

In prostate cancer the gland drastically changes your tissue organization, with reduction of smooth muscle cells. Figures $2 \mathrm{~A}$ and $2 \mathrm{~B}$, show the presence and organization of typical eosinophil and mastocyte. Eosinophil (Fig. 2A) is shown as a bilobed nucleus cell (histologically cut) with a cytoplasm loaded with acidophilic-like granulations (arrow). Reference bar $10 \mu \mathrm{m}$. Mast cells (Fig. 2B) were observed with a single whole nucleus and a cytoplasm loaded with typical metachromatic granulations (arrow).

In the quantification of the number of cells by areas $\left(0.17 \mathrm{~mm}^{2}\right)$ in normal prostate, no eosinophils or mast cells were identified. However, in biopsies diagnosed with cancer, eosinophils have a concentration of $0.155 \pm 0.218$ (cells / 0.17 $\mathrm{mm}^{2}$ ) and mast cells a concentration of $0.169 \pm 0.835$ (cells / $0.17 \mathrm{~mm}^{2}$ ), with coefficients of variation of 1.4 and 4.9 respectively. Table I shows the correlation coefficients (Pearson and Spearmen) between age and the histological characteristics quantified in each biopsy. It is observed that these variables have a positive correlation with high significance between age Gleason index and mast cell concentration. IA, shows a high correlation between the age and Gleason index (Pearson $* * p<0.001$ ) but not in relation of presence of eosinophils. IB, shows a high correlation between the presence of mast cells the age and Gleason index (Pearson and Spearmen *p< $0.05 ; * \mathrm{p}<0.01)$.
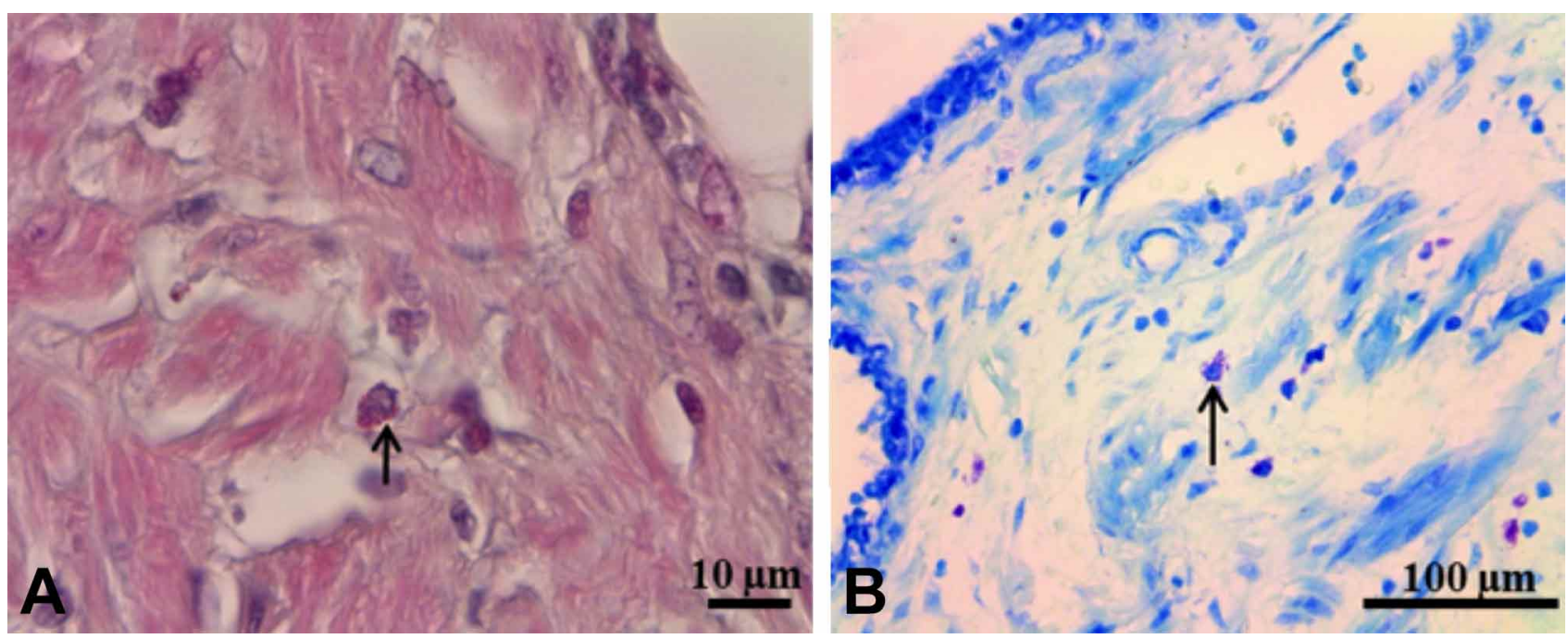

Fig. 2. Photomicrographs of the histology of the prostate with a diagnosis of confirmed cancer, specific stains for eosinophils - Giemsa stain (2A arrow). Reference bar $10 \mu \mathrm{m}$ and mast cells - Toluidin blue stain (2B arrow). Increase to 40X, $0-17 \mathrm{~mm}^{2}$ field diameter reference bar $100 \mu \mathrm{m}$. 
Table I. In A, multiple correlation coefficients are shown for the variables: Age, minor Gleason, Major Gleason, Total Gleason, and Eosinophil cell concentration (Pearson and Spearman, with values of $* \mathrm{p}<0.05$ and $* * \mathrm{p}<0.01)$. In B, multiple correlation coefficients are shown for the variables: Age, minor Gleason, Major Gleason, Total Gleason, and mast cell concentration (Pearson and Spearman, with values of $* \mathrm{p}<0.05$ and $* * \mathrm{p}<0.01)$.

\begin{tabular}{cccccc}
\hline A & Correlations & \multicolumn{3}{c}{ Gleason Index } & Cell types \\
& & Minor & Major & Total & Eosinophils \\
\hline Age & Pearson & $0.787^{* *}$ & $0.739^{* *}$ & $0.803^{* *}$ & 0.098 \\
& $\mathrm{n}$ & 27 & 27 & 27 & 27 \\
Age & Spearman & $0.461^{*}$ & 0.236 & 0.365 & 0.224 \\
& $\mathrm{n}$ & 27 & 27 & 27 & 27 \\
$\mathrm{~B}$ & & & & & \\
Age & Pearson & $0.889^{* *}$ & $0.893^{* *}$ & $0.926^{* *}$ & $0.625^{* *}$ \\
& $\mathrm{n}$ & 18 & 18 & 18 & 18 \\
Age & Spearman & $0.584^{*}$ & $0.722^{* *}$ & $0.716^{* *}$ & $0.737^{* *}$ \\
& $\mathrm{n}$ & 18 & 18 & 18 & 18 \\
\hline & $* \mathrm{p}<0.05 ; * * \mathrm{p}<0.001$ & & &
\end{tabular}

\section{DISCUSSION}

Eosinophils are granulocytic leukocytes circulating in the blood, and absent or in small quantities in healthy lung-like tissues, mammary gland, digestive and reproductive systems. An increase in the eosinophilia, is not common in healthy individuals. However, eosinophilia has been described in association with a diagnosis of colorectal, breast, ovarian, cervical, oral, and prostate cancer. Eosinophil infiltration in tissues diagnosed with cancer is known to be unfavorable to the patient's prognosis. They secrete a wide variety of cationic cytokine/protein-like molecules, neurotoxins, peroxidase, and others, which together could exert anti-tumor action or at another time, facilitating tumor progression (Sakkal et al., 2016).

Mast cells can always be on alert and respond to a wide variety of external environmental signals and the products of the loss of endogenous homeostasis (inflammation, necrosis, and cancer), releasing chemical mediators of local and systemic action. This cell type is supposed to have epigenetic and transcriptional programs that allow them to maintain stable identities and plasticity of environmental adaptation (Monticelli \& Leoni, 2017; Espinosa \& Valitutti, 2017).

In this study the patients with confirmed prostate cancer, the histological presence of eosinophilia and tissue mastocytosis were observed (Figs. 1 and 2). Table I show that the patient's age is a factor of high relevance in the presentation, development, and prognosis of prostate cancer since the correlations between age and different grades of Gleason is positive and close to 1.0 (Pearson and Spearmen $* \mathrm{p}<0.05$ ).

In biopsies that confirm the diagnosis of prostate cancer, a variety of cell types associated with inflammation and response in oncogenic progress have been described: innate and adaptive immunity cells, B and T lymphocytes, macrophages, natural killer, cells dendritic, neutrophils, and mast cells, all of them as infiltrates in the connective tissues and epithelium of the gland (Taverna et al., 2013).

Prostate carcinoma is a cancer of solid consistency generated by the coexistence of infiltration of inflammatory cells and dedifferentiation towards the stroma of epithelial cells. Parallel to the beginning of tissue damage there is the release of IL-33 (from the IL-1 family) that is released as a result of a cellular or tissue injury to alert the immune system that express the IL-1RL1 receptor (ST2), including mast cells, eosinophils and B lymphocytes (Cayrol \& Girard, 2018).

In a state of tissue normality, the regulated degranulation of mast cells allows modulating the effects of cellular metabolism and acidity constants of tissue fluids. Additionally, Espinosa \& Valitutti, add that mast cells can efficiently combat the presence of pathogens, favor the chemical clearance of tissues, and contribute to tissue homeostasis.

In an inflammatory state, such as in the skin, the progress of the process ranges from expanding erythema, accumulation of inflammatory cells in the affected tissues with consequent activation of mast cells, degranulation, and release of pro-inflammatory cytokine mediators and bioactive lipids, which expand the effects and the initial inflammatory reaction, significantly contributing to the structural and biochemical damage of the basal lamina (Joseph et al., 2016). Galdiero et al. (2017) mention that both mast cells and eosinophils are cells present in the cancer process, being the eosinophils modulated by mast cells. Therefore, among them, there would be a bidirectional modulation in the progress or remission of the pathology.

In solid tumors, the development of eosinophilia has been described. Although, it is not yet discussed whether this feature alone is a pro-cancer or anti-cancer. Even eosinophilia has been associated with good prognosis in cases of colorectal and prostate cancer (Davis \& Rothenberg, 2014; Galdiero et al.). Although, their bidirectional action with mast cells can 
influence angiogenesis and lymph tumor angiogenesis by adding a multidirectional action between them and with the rest of the neighboring cells and the tumor microenvironment (Galdiero et al.).

In the prostate, the structural and functional existence of smooth muscle fibers in the stroma and basal lamina of type IV collagen can be very vulnerable to these new biochemical microenvironments. In the gastrointestinal system, hyper reactivity of smooth muscle cells has been described in the setting of mast cells and eosinophils (Finkelman et al., 2004; Anthony et al., 2007).

Innate immune system cells function as efficient early sentinels, which then interact with the adaptive immune system, detecting environmental changes and releasing regulatory cytokines from the immune system. In the oncogenic development of the prostate, the presence of specific infectious agents of the disease may not be present. The pathological process would be a response to an oxidized altered metabolic state where the body's cells try to regulate the multidirectional concert of molecules and cells. Participants in this process mast cells and eosinophils are prominent in the development of tumorigenesis. It is possible that overexpression of mast cells may be caused by the action of eosinophils, an important factor to consider in the prognosis of the disease (Hogan et al.; Rodríguez et al.).

\section{CONCLUSIONS}

It is concluded that in prostate biopsies from Chilean patients with confirmed cancer, eosinophilia and tissue mastocytosis were observed. Correlation analyzes show a direct correlation between older patients, higher Gleason index and presence of mast cell. Regarding eosinophilia, only a correlation between age and Gleason index was observed Further studies are suggested to determine that the presence of eosinophils and mast cells can be used as early bioindicators of prostate cancer.

RODRÍGUEZ, H.; CORTÉS-CHAU, F.; CORTÉS-PINO, F.; AGUIRRE, P.; BRAVO, G.; GALLEGOS, I.; ARRIAZA, C.; CUÉLlAR, C.; AGUAYO, F. \& ESPINOZA-NAVARRO, 0. Cambios morfológicos de la celularidad en la glándula prostática de pacientes con cáncer confirmado: Nivel de Gleason y presencia de eosinófilos y mastocitos: bioindicadores celulares. Int. J. Morphol., 38(4):882-887, 2020

RESUMEN: Las diferentes patologías de próstata, involucran la presencia de un nuevo microambiente donde las células inflamatorias son activamente reclutadas. La presente inves- tigación explora la presencia de mastocitos y eosinófilos asociadas a la edad y la evaluación del progreso del cáncer de próstata según índice de Gleason. Cuarenta y dos biopsias de pacientes anonimizados, con cáncer prostático confirmados, fueron utilizadas para su análisis histológico para eosinófilos y mastocitos y posterior determinación del índice de Gleason según edad. Los resultados de los análisis histológicos, muestran la presencia de eosinófilos y mastocitos en biopsias de próstata con cáncer confirmado. En los estudios de correlación múltiple, se observó una alta correlación entre la presencia de linfocitos, mastocitos y la edad del paciente diagnosticado con cáncer prostático, igual correlación se observó entre la edad del paciente y mayor índice de Gleason (Pearson y Spearman $\mathrm{p}<0,05$ ). Se concluyó que en las biopsias de próstata de pacientes chilenos con cáncer confirmado, se observó eosinofilia y mastocitosis tisular. Los análisis de correlación muestran una correlación directa entre pacientes de mayor edad, índice de Gleason más alto y la presencia de mastocitos. Con respecto a la eosinofilia, solo se observó una correlación entre la edad y el índice de Gleason. Se sugieren estudios adicionales para determinar que la presencia de eosinófilos y mastocitos puede usarse como bioindicadores tempranos del cáncer de próstata.

PALABRAS CLAVE: Bioindicadores prostáticos; Diagnóstico precoz; Cáncer; Microambiente celular.

\section{REFERENCES}

Akuthota, P.; Wang, H. B.; Spencer, L. A. \& Weller, P. F. Immunoregulatory roles of eosinophils: a new look at a familiar cell. Clin. Exp. Allergy, 38(8):1254-63, 2008

Anthony, R. M.; Rutitzky,L. I.; Urban, J. F. Jr.; Stadecker, M. J. \& Gause, W. C. Protective immune mechanisms in helminth infection. Nat. Rev. Immunol., 7(12):975-87, 2007.

Carmeliet, P. Angiogenesis in health and disease. Nat. Med., 9(6):653-60, 2003.

Cayrol, C. \& Girard, J P. Interleukin-33 (IL-33): A nuclear cytokine from the IL-1 family. Immunol. Rev., 281(1):154-68, 2018.

Chao, J.; Li, P. \& Chao, L. Kallistatin suppresses cancer development by multi-factorial actions. Crit. Rev. Oncol. Hematol., 113:71-8, 2017.

Davis, B. P. \& Rothenberg, M. E. Eosinophils and cancer. Cancer Immunol. Res., 2(1):1-8, 2014.

Espinosa, E. \& Valitutti, S. New roles and controls of mast cells. Curr. Opin. Immunol., 50:39-47, 2017.

Finkelman, F. D.; Shea-Donohue, T.; Morris, S. C.; Gildea, L.; Strait, R.; Madden, K. B.; Schopf, L. \& Urban, J. F. Jr. Interleukin-4- and interleukin-13-mediated host protection against intestinal nematode parasites. Immunol. Rev., 201:139-55, 2004.

Galdiero, M. R.; Varricchi, G.; Seaf, M.; Marone, G.; Levi-Schaffer, F. \& Marone, G. Bidirectional mast cell-eosinophil interactions in inflammatory disorders and cancer. Front. Med. (Lausanne), 4:103, 2017.

Gao, Z. G. \& Jacobson, K. A. Purinergic signaling in mast cell degranulation and asthma. Front. Pharmacol., 8:947, 2017.

Globa, T.; Saptefrti, L.; Ceausu, R. A.; Gaje, P.; Cimpean, A. M. \& Raica, M. Mast cell phenotype in benign and malignant tumors of the prostate. Pol. J. Pathol., 65(2):147-53, 2014.

Hogan, S. P.; Rosenberg, H. F.; Moqbel, R.; Phipps, S.; Foster, P. S.; Lacy, P.; Kay, A. B. \& Rothenberg, M. E. Eosinophils: biological properties and role inhealth and disease. Clin. Exp. Allergy, 38(5):709-50, 2008. 
Joseph, L. B.; Composto, G. M. \& Heck, D. E. Tissue injury and repair following cutaneous exposure of mice to sulfur mustard. Ann. N. Y. Acad. Sci., 1378(1):118-23, 2016.

Kimura, Y. N.; Watari, K.; Fotovati. A.; Hosoi, F.; Yasumoto, K.; Izumi, H.; Kohno, K.; Umezawa, K.; Iguchi, H.; Shirouzu, K.; et al. Inflammatory stimuli from macrophages and cancer cells synergistically promote tumor growth and angiogenesis. Cancer Sci., 98(12):200918, 2007.

Lima, A. R.; Bastos, M. de L.; Carvalho, M. \& Guedes de Pinho, P. Biomarker discovery in human prostate cancer: an update in metabolomics studies. Transl. Oncol., 9(4):357-70, 2016.

McEllistrim, C.; Krawczyk, J. \& O’Dwyer, M. E. New developments in the treatment of multiple myeloma - clinical utility of daratumumab. Biologics, 11:31-43, 2017.

Ministerio de Salud (MINSAL), Comisión Ministerial de Ética en Investigación en Salud. (CMEIS). Acceso Excepcional a la Ficha Clínica sin Consentimiento Informado, con Fines de Investigación. Análisis Normativo: Ético y Jurídico. Santiago de Chile, Ministerio de Salud, Gobierno de Chile, 2015.

Monticelli, S. \& Leoni, C. Epigenetic and transcriptional control of mast cell responses. F1000Res., 6:2064, 2017.

Pin, E.; Fredolini, C. \& Petricoin, E. F. 3rd. The role of proteomics in prostate cancer research: biomarker discovery and validation. Clin. Biochem., 46(6):524-38, 2013.

Rodríguez, H.; Levican, J.; Muñoz, J. P.; Carrillo, D.; Acevedo, M. L.; Gaggero, A.; León, O.; Gheit, T.; Espinoza-Navarro, O.; Castillo, J.; et $a l$. Viral infections in prostate carcinomas in Chilean patients. Infect. Agents Cancer, 10:27, 2015.

Sakkal, S.; Miller, S.; Apostolopoulos, V. \& Nurgali, K. Eosinophils in cancer: favourable or unfavourable? Curr. Med. Chem., 23(7):650-66, 2016.

Sfanos, K. S.; Hempel, H. A. \& De Marzo, A. M. The role of inflammation in prostate cancer. Adv. Exp. Med. Biol., 816:153-81, 2014.

Sridharan, G. \& Shankar, A. A. Toluidine blue: A review of its chemistry and clinical utility. J. Oral Maxillofac. Pathol., 16(2):251-5, 2012.

Taverna, G.; Giusti, G.; Seveso, M.; Hurle, R.; Colombo, P.; Stifter, S. \& Grizzi, F. Mast cells as a potential prognostic marker in prostate cancer. Dis. Markers, 35(6):711-20, 2013.

Wong, Y. C. \& Tam, N. N. Dedifferentiation of stromal smooth muscle as a factor in prostate carcinogenesis. Differentiation, 70(9-10):633-45, 2002.

\author{
Corresponding author: \\ Prof. Dr. Omar Espinoza Navarro \\ Faculty Science \\ Department Biology \\ Universidad de Tarapacá \\ Av. General Velásquez No 1775 \\ Arica \\ CHILE
}

Email: omarespinoza091@gmail.com

Received: 27-12-2019

Accepted: 10-02-2020 